\title{
Bioactive compound retention in frozen red and yellow Strawberry guava pulps added with L-Ascorbic acid
}

\author{
Lisiane Pintanela Vergara ${ }^{1}$, Gabriela Niemeyer Reissig ${ }^{2}$, Rodrigo Cezar Franzon ${ }^{3}$, \\ Rosane da Silva Rodrigues ${ }^{4}$, Josiane Freitas Chim ${ }^{5}$ \\ Abstract - Brazil presents a great variety of native fruits, which have aroused commercial \\ interest, such as the strawberry guava. In this sense, many researches have looked for alternatives \\ that allow postharvest availability of fruits, considering that perishability is a limiting factor for \\ its commercialization. The freezing process is an important alternative in the sense of making \\ these fruits available for longer on the market. The use of L-ascorbic acid is a potent protective \\ agent in the stability of bioactive compounds in fruit pulps. The objective of this study was to \\ evaluate potentially bioactive compounds present in red and yellow strawberry guava pulps \\ added with L-ascorbic acid $(1 \% \mathrm{~m} / \mathrm{m})$ and verify its effect on retention of these compounds \\ and in its antioxidant activity during the frozen storage $\left(-20 \pm 2^{\circ} \mathrm{C}\right)$. In the pulps were analyzed: \\ antioxidant activity by the capture of the $\mathrm{DPPH}^{\circ}$ and $\mathrm{ABTS}^{\circ}$ radicals, phenols, anthocyanins and \\ total carotenoids. L-ascorbic acid positively influences the retention of bioactive compounds (total \\ phenols, total anthocyanins and total carotenoids) in red and yellow strawberry guava pulps during \\ 120 days of frozen storage $\left(-20 \pm 2{ }^{\circ} \mathrm{C}\right)$. \\ Index terms: native fruits; Psidium cattleianum Sabine; phytochemicals; antioxidant; storage.

\section{Retenção de compostos bioativos em polpas congeladas de Araçás- vermelho e amarelo adicionadas com ácido L-Ascórbico}

Corresponding author: lisianevergara@yahoo.com.br

Received: March 19, 2018 Accepted: September 14, 2018

Copyright: All the contents of this journal, except where otherwise noted, is licensed under a Creative Commons Attribution License.

\section{(cc) $\mathbf{E Y}$}

Resumo-O Brasil apresenta grande variedade de frutas nativas que têm despertado interesse comercial, a exemplo do araçá. Nesse sentido, muitas pesquisas têm buscado alternativas que permitam a disponibilidade do fruto pós-colheita, considerando que a perecibilidade é um fator limitante para sua comercialização. O processo de congelamento é uma alternativa importante no sentido de disponibilizar esses frutos por mais tempo no mercado. O uso de ácido L-ascórbico é um potente agente protetivo na estabilidade de compostos bioativos em polpas de frutas. $\mathrm{O}$ estudo teve como objetivo avaliar compostos potencialmente bioativos, presentes em polpas de araçás-vermelho e amarelo adicionadas de ácido L-ascórbico $(1 \% \mathrm{~m} / \mathrm{m})$ e verificar sua ação na retenção destes compostos em sua atividade antioxidante durante o armazenamento congelado (-20 $\pm 2^{\circ} \mathrm{C}$ ). Nas polpas, foram analisados: atividade antioxidante pela captura dos radicais $\mathrm{DPPH}^{\circ} \mathrm{e}$ $\mathrm{ABTS}^{\circ}$, fenóis, antocianinas e carotenoides totais. O ácido L-ascórbico influencia positivamente na retenção dos compostos bioativos (fenóis totais, antocianinas totais e carotenoides totais) em polpas de araçás-vermelho e amarelo, durante 120 dias de armazenamento congelado $\left(-20 \pm 2^{\circ} \mathrm{C}\right)$. Termos para indexação: fruta nativa; Psidium cattleianum Sabine; fitoquímicos; antioxidante; armazenamento. 


\section{Introduction}

Brazil presents a great variety of native fruits, which has aroused commercial interest. The strawberry guava (Psidium cattleianum Sabine) belongs to the Myrtaceae family and it is a globular fruit, yellow or red, with a juicy pulp and a very pleasant sweet-acid taste. It is rich in bioactive substances, especially in phenolic compounds and carotenoids, which have stimulated consumption; however, the fact that it is very perishable makes its fresh commercialization difficult (LORENZI, 2006; FRANZON, 2009). Its distribution occurs in several regions of the country, from subtropical to temperate climate (BIEGELMEYER et al., 2011; DENARDIN et al., 2015; RIBEIRO et al., 2014).

The strawberry guava tree still does not have commercial cultivation, being its fruits harvested in an extractive way and whose commercial exploitation is restricted to the familiar agriculture. However, there is a growing interest in cultivation, particularly by small farmers, considering that the market for small fruits, mainly native, has a high marketing potential. Besides the possibility of exploitation for consumption of fresh fruits, it has already demonstrated a potential for processing juices, nectars, yogurts, ice creams, candies, jellies, and pulps (REISSIG, 2016).

Rapid darkening of fruit pulp is a limiting aspect of processing. It is due to the production of brown-colored polymers (melanoidins) from enzyme catalyzed reactions, such as peroxidase and polyphenoloxidase (TOMÁSBARBERÁN; SPÍN, 2001; VILAS-BOAS, 2002). The application of antioxidant agents has been an alternative to inhibit these reactions of darkening, resulting in better sensorial characteristics thus allowing to preserve the bioactive compounds present in the pulp. Citric acid, L-ascorbic acid, sodium isoascorbate, sodium erythorbate are some examples of commercially used compounds that exert antioxidant activity, avoiding enzymatic browning (BARRETO et al., 2016).

Brazilian legislation recommends the use of food additives in fruit pulp and their respective amounts. L-ascorbic acid can be used as an antioxidant in fruit pulp in the amount needed to achieve the desired effect (quantum satis) (BRASIL, 2013).

Along with its neutral salts, $\mathrm{L}$-ascorbic acid is one of the main antioxidants used in plant products to prevent browning and other oxidative reactions in two ways: (1) by acting directly on the enzyme, complexing the copper of the prosthetic group of the polyphenoloxidase, causing its inhibition; and (2) by reducing the quinones to their previous form of phenols, preventing the formation of dark pigments (SAPERS; MILLER, 1998). The reduction of quinones to their phenolic precursors leads to the irreversible oxidation of L-ascorbic acid (which is preferably oxidized instead of phenolic compounds) and the formation of dehydro ascorbic acid without inhibitory activity (MARSHALL et al., 2000).

Based on the premise that L-ascorbic acid can positively influence the preservation of bioactive compounds (total phenols, total anthocyanins and total carotenoids) of red and yellow strawberry guava pulps, the objective of this study was to verify its action on the retention of these compounds and their antioxidant activity during frozen storage $\left(-20 \pm 2^{\circ} \mathrm{C}\right)$.

\section{Material and methods}

The red and yellow fruits from strawberry guava trees were harvested ripe (red and yellow uniform colorations of the peel), in the first quarter of 2015 of plants kept in the collection of strawberry guava, strawberry and cherry of Embrapa Clima Temperado, Pelotas - RS (geographical coordinates : $31^{\circ} 40$ ' $47^{\circ}$ "S and $52^{\circ} 26^{\prime} 24^{\prime \prime} \mathrm{W}: 60 \mathrm{~m}$ altitude).

Fruits were selected, washed with water and sanitized with chlorine solution at $200 \mathrm{mg} / \mathrm{l}$ and pulped in a horizontal removing device ( $2 \mathrm{~mm}$ mesh). The pulps obtained from red and yellow strawberry guava fruits were separated into two fractions: the first, as a control, without addition of L-ascorbic acid (P1c: control red strawberry guava pulp, P2c: control yellow strawberry guava pulp) and the second fraction was added with L-ascorbic (P1: red strawberry guava pulp added with L-ascorbic acid, $\mathrm{P} 2$ : yellow strawberry guava pulp added with L-ascorbic acid) $1 \%(\mathrm{~m} / \mathrm{m})$ of $\mathrm{L}$-ascorbic acid was used in pulps treated with antioxidant, and the legislation does not recommend a necessary amount. The pulps were packed in high density polyethylene bags and kept under freezing $\left(-20 \pm 2{ }^{\circ} \mathrm{C}\right)$ for 1,60 and 120 days.

During the pulp storage (1, 60 e 120 days) were evaluated total phenols, total anthocyanins, total carotenoids, and antioxidant active by the capture of DPPH and ABTS radicals. For phenolic compounds quantification, a methodology adapted from Singleton and Rossi (1965) was used. To obtain the pulp extract, 2 $\mathrm{g}$ of sample were weighed, placed in $50 \mathrm{ml}$ falcon tubes protected from light and homogenized for one minute in Ultra Turrax ${ }^{\circledR}$ (IKA ${ }^{\circledR}$, T18 digital) at $7500 \mathrm{rpm}$ for one minute with $20 \mathrm{~mL}$ methanol PA. Then centrifuged for 15 minutes at $7000 \mathrm{rpm}$ in a centrifuge (Eppendorf Centrifuge, 5430) cooled to $4^{\circ} \mathrm{C}$. The supernatant was transferred to light-protected $15 \mathrm{ml}$ falcon tubes. For the colorimetric reaction, an aliquot of $500 \mu \mathrm{L}$ of the extract was diluted in $4 \mathrm{~mL}$ of distilled water and the control prepared with $250 \mu \mathrm{L}$ of methanol. $250 \mu \mathrm{L}$ of $0.25 \mathrm{~N}$ Folin-Ciocalteau solution was added and after 3 minutes $500 \mu \mathrm{L}$ of $1 \mathrm{~N}$ sodium carbonate was added. After 2 hours of reaction, the sample absorbance was read in a spectrophotometer (Jenway, $6700 \mathrm{UV}-\mathrm{Vis}$ ), at wavelength 
$725 \mathrm{~nm}$, and the results were expressed as mg of gallic acid $100 \mathrm{~g}^{-1}$. The determination of total anthocyanins was performed according to the methodology described by Lees and Francis (1972). For the preparation of the extract, $2 \mathrm{~g}$ of sample and methanol $\mathrm{pH} 1.0$ were used. The absorbance was determined by spectrophotometric reading (Jenway, $6700 \mathrm{UV}$-Vis) at a wavelength of $520 \mathrm{~nm}$, and the results were expressed as mg of cyanidin-3-glycoside $100 \mathrm{~g}^{-1}$. Total carotenoids were determined by the modified method 970.64 from AOAC International (2005). $2.5 \mathrm{~g}$ of sample were weighed into $50 \mathrm{ml}$ falcon tubes protected from light. $15 \mathrm{~mL}$ of extractive solution (hexane: acetone: ethyl alcohol: toluene, 10: 7: 6:7) was added and then stirred for 30 seconds in a vortex (Phoenix, AP-56). $1 \mathrm{~mL}$ of $10 \%$ potassium hydroxide in methanol $(\mathrm{m} / \mathrm{v})$ was added and mixed in a vortex (Phoenix, AP-56) for one minute and then submitted to hot saponification (keeping the tubes falcon 20 minutes in a water bath at $56^{\circ} \mathrm{C}$ ). After this period, the samples were kept at room temperature (in the exhaust hood) for one hour. Then $15 \mathrm{~mL}$ of petroleum ether were added to the tubes and completed the volume of the falcon tube with $10 \%$ sodium sulfate solution in water $(\mathrm{m} / \mathrm{v})$. The mixture was hold for one hour at rest and read the supernatant in a spectrophotometer (Jenway, $6700 \mathrm{UV}$-Vis) at the wavelength of $450 \mathrm{~nm}$. The results were expressed as $\mathrm{mg}$ of $\beta$-carotene $100 \mathrm{~g}^{-1}$. Two different methods were used to determine total antioxidant capacity, DPPH and ABTS radical method. Capture of the $\mathrm{DPPH}^{\circ}$ radical (2,2-diphenyl-1-picryl-hydrazyl) was determined by the method adapted from Brand-Williams et al. (1995). For the reaction, $100 \mu \mathrm{L}$ of the same extract used for the determination of total phenolic compounds and $3.9 \mathrm{~mL}$ of DPPH solution in methanol (showing absorbance of $1.10 \pm 0.02$ ) were added. The mixture was vortexed (Phoenix, AP-56) and the vials kept in the dark for 24 hours. Parallel to the sample, a blank test $(100 \mu \mathrm{L}$ of methanol P.A. and $3.9 \mathrm{~mL}$ of $\mathrm{DPPH}^{\circ}$ solution) was performed. The reading was performed at the wavelength of $517 \mathrm{~nm}$ in a spectrophotometer (Jenway, $6700 \mathrm{UV}$-Vis). The results were expressed as percent inhibition of the $\mathrm{DPPH}^{\circ}$ radical. Capture of the $\mathrm{ABTS}^{\circ}$ radical (2,2-azinobis3-ethylbenzthiazoline-6-sulfonic acid) was determined by the method adapted from Rufino et al. (2007). The radical was formed from the reaction of $88 \mu \mathrm{L}$ of 140 $\mathrm{mM}$ potassium persulfate solution in $5 \mathrm{~mL}$ of $\mathrm{ABTS}^{\circ}$ solution $(7 \mathrm{mM})$, kept in the dark at room temperature for 16 hours. Then $1 \mathrm{~mL}$ of this mixture was diluted to absolute ethyl alcohol until an absorbance of $0.700 \pm 0.05$ was obtained at $734 \mathrm{~nm}$ wavelength. For the reaction in 15 $\mathrm{mL}$ falcon tubes, a $30 \mu \mathrm{L}$ aliquot of the same extract used for quantification of total phenolic compounds and $3.0 \mathrm{~mL}$ of the $\mathrm{ABTS}^{\circ}$ radical was transferred. The mixture was homogenized in vortex (Phoenix, AP-56) and analyzed in a spectrophotometer at $734 \mathrm{~nm}$ (Jenway, $6700 \mathrm{UV}-\mathrm{Vis}$ ) after six minutes of reaction. The results were expressed as percent inhibition of the $\mathrm{ABTS}^{\circ}$ radical.

The chemical analyses data of each pulp (red and yellow) treated with L-ascorbic acid and control were submitted to analysis of variance (ANOVA) and, in case of significant difference, submitted to comparison of means by test $\mathrm{T}(\mathrm{p} \leq 0.05)$ and, among storage times, in case of significant difference, submitted to comparison of means by Tukey's test $(\mathrm{p} \leq 0.05)$ using the program STATISTICA 7.0 (STATSOFT, 2004).

\section{Results and discussion}

Red strawberry guava pulp added with L-ascorbic acid $(\mathrm{P} 1)$ differed $(\mathrm{p} \leq 0.05)$ from its control $(\mathrm{P} 1 \mathrm{c})$ for total phenolic content (Table 1). During the storage of red strawberry guava pulp without antioxidant addition (control), there was an increase in the content of the phenolic compounds in the first 60 days of storage, presenting a subsequent reduction of $15.75 \%$ from the 120 days of storage in the contents of these compounds (Figure 1). According to Sellappan et al. (2002) and Araújo (2009), this behavior may be due to copigmentation reactions occurring during storage. According to Menezes (1994) and Araújo (2009), the reduction of these compounds may be due to processes of complexation and polymerization of tannins.

The content of phenolic compounds did not differ during the first and 120 days of storage of the added L-ascorbic acid (P1) pulp, indicating that the amount of $\mathrm{L}$-ascorbic acid added in the pulp in this study was efficient for the retention of these compounds at the end of the 120 days of storage at the temperature used in the study (Figure 1). Shiassi et al. (2018) quantified phenolic compounds in frozen fruit pulps of Brazilian Cerrado, finding $89.14 \mathrm{mg}$ of gallic acid $100 \mathrm{~g}^{-1}$ in strawberry guava pulp. In other studies made with frozen pulps of blackberry (Rubus sp), blueberry (Vaccinium ashei Reade), red strawberry guava (Psidium cattleyanum Sabine) and butiá (Butia odorata), phenolic compounds contents of 1036.0 were quantified for pulp of red strawberry guava in $\mathrm{mg}$ of chlorogenic acid equivalent $100 \mathrm{mg}^{-1}$ (VIZZOTTO et al., 2012). According to Souza et al. (2012) and Shiassi et al. (2018), climatic conditions, soil composition, adequate fruit management, as well as the extraction method applied during the analyzes, are the main factors that directly interfere in the content of phenolic compounds determined in this study.

Yellow strawberry guava pulp added with $\mathrm{L}$-ascorbic acid (P2) differed $(\mathrm{p} \leq 0.05)$ from the control (P2c) in relation to the total phenolic content (Table 2). The antioxidant-treated yellow strawberry guava pulp presented a higher content of phenolic compounds during the 120 days of storage compared to the control, fact that was already expected and also verified in the red strawberry guava pulp, as explained previously (Figure 
1). Crizel et al. (2017), quantified the content of phenolic compounds in frozen yellow strawberry guava pulp, where they found $70.8 \mathrm{mg}$ of gallic acid per $100 \mathrm{~g}^{-1}$ dry sample. The content of phenolic compounds in fruits depends on the species, variety, environment, physiological status, and climatic conditions (SCALBERT and WILLIAMSON, 2000), as well as the selectivity of polyphenoloxidases for anthocyanins (ZHANG et al., 2005). These factors may have contributed to the differences in phenolic compound values found by the authors.

The P1 treatment did not differ significantly from the P1c control in the total anthocyanins content on the first day of storage (Table 1). In the P1c treatment, there was a reduction of $31.21 \%$ and $5.67 \%$ at 60 and 120 days of storage, respectively (Figure 2). Jacques et al. (2009), when evaluating the stability of frozen blackberry pulp at different temperatures $\left(-10,-18\right.$ and $\left.-80^{\circ} \mathrm{C}\right)$, observed losses of anthocyanins in the fourth month of storage. The degradation of these pigments can be favored by enzymatic action, considering that the pulp produced was not subjected to thermal inactivation treatment (JACQUES et al., 2009). As well as for other physicochemical parameters, many factors may influence the content and composition of anthocyanins. Differences among cultivars may have quantitative and qualitative influences, while maturation may lead to an increasing pigment's content (BOYLES and WROLSTAD, 1993; BALDI et al., 1995). The $\mathrm{P} 1$ treatment did not change its content of anthocyanins throughout the 120 days of storage (Figure 2). In the treatment $P 1 \mathrm{c}$ and $\mathrm{P} 2 \mathrm{c}$ there was a peak in the content of anthocyanins at 120 days of storage, a fact that did not occur in the treatments with antioxidant. Probably the increase of stability occurred because the copigment competes with water and interacts with the anthocyanins, complexing the colored forms and modifying the nature of the copigment (FALCÃO et al., 2003; MAZZA and MINIATI, 1993). In the present study, it is possible to observe the increase in absorbance values (hyperchromic effect) and batocromic displacement (generally between 5 and $20 \mathrm{~nm}$ or more in the wavelength of maximum absorption) (FALCÃO et al., 2003; BOULTON, 2001; MAZZA and MINIATI, 1993; BROUILLARD, 1983; TIMBERLAKE, 1980).

The P2 treatment did not differ from the P2c treatment in total anthocyanins content on the first day of storage (Table 2). In the P2 treatment, there was a reduction of $83.33 \%$ and $62.04 \%$ at 60 and 120 days of storage, still the total anthocyanins content in the P2c treatment remained stable during the first 60 days of frozen storage (Figure 2). According to BOBBIO and BOBBIO (1992) and MAEDA et al. 2007, anthocyanins interact with ascorbic acid, metals, sugars, oxygen, light, temperature, and enzymes, producing polymers of degradation products that decrease their stability. According to JURD (1972) and MAEDA et al. (2007), there is a condensation reaction between ascorbic acid and anthocyanins, and, in this relation, the higher the concentration of this vitamin in the system, the higher the degradation rate of the anthocyanin pigment.

In red strawberry guava pulp treatments, $\mathrm{P} 1$ and $\mathrm{P} 1 \mathrm{c}$ treatments differed in relation to total carotenoids on the first storage day (Table 1). However, the yellow strawberry guava pulps (P2c and P2) did not differ significantly for these compounds (Table 2). The highest values of carotenoids in the frozen red and yellow strawberry guava pulps added with L-ascorbic acid and their controls were observed at 60 and 120 days of storage (Figure 3), which may be due to unaccounted water losses in the unprocessed frozen pulp or the higher extractability of the analyte in the processed sample, making the carotenoid more available (RODRIGUEZ-AMAYA et al., 2008). Carotenoids, besides giving the fruit a characteristic color, are bioactive compounds of importance in human nutrition for its antioxidant properties, acting in the capture of free radicals (PALIYATH et al., 2008). Lopes et al. (2005) evaluated the stability of frozen pitanga (Eugenia uniflora L.) pulp over a period of 90 days of storage and found that there was a significant loss of total carotenoid content in the first 30 days of storage, but at 45, 60, and 90 days there was no significant decrease. Aquino et al. (2011), when evaluating the stability of frozen acerola (Malpighiaemarginata D.C.) pulp, reported significant decrease in total carotenoid contents after 60 days of storage. The synthesis of these compounds is influenced by several factors, such as genetic component, stage of development, availability of nutrients in the soil, temperature, and, in particular, luminosity, which may explain the differences found (MUNHOZ et al., 2014). The degree of maturation and the extraction method are also factors that can lead to differences in the quantification of these compounds.

The P2 and P1 treatments presented higher antioxidant activity than the $\mathrm{P} 2 \mathrm{c}$ and $\mathrm{P} 1 \mathrm{c}$ control ones, both by the DPPH and ABTS radical method on the first day of storage (Table 1 and Table 2). As L-ascorbic acid functions as a reducing agent, it is understandable the greater antioxidant activity in these pulps. In yellow strawberry guava pulps, both treatments (control and with addition of L-ascorbic acid) showed a preservation of $94.20 \%$ and $82.6 \%$ in the antioxidant activity measured through the DPPH radical method, during the 120 days of storage (Figure 4). In the control treatment, in both strawberry guava pulps there was greater antioxidant activity at 60 days of storage, through the DPPH and ABTS radical methods (Figure 4). While for the red strawberry guava pulp at 120 days, the control presented greater activity by the ABTS method (Figure 4). This increase in the antioxidant activity can be explained by the rupture and decompression of the tissues, which may have facilitated the contact with the solvent, allied to the 
chemical composition and reactions during the freezing of the pulp (NORA, 2012).

It was observed that the antioxidant activity evaluated by the capture of the DPPH radical in red strawberry guava pulps was higher than the one found by the capture of the ABTS radical. The ABTS method measures the antioxidant activity of a range of carotenoids and phenolic compounds, determined by the discoloration of ABTS through the measurement of the radical reduction with the absorbance percentage inhibition at $734 \mathrm{~nm}$ (RE et al., 1999; CASTELUCCI, 2015). In the DPPH method, the measurement is given by decreasing the absorbance at $515 \mathrm{~nm}$ through the free radical capture by the sample (CASTELUCCI, 2015). The DPPH method has advantages when the analyzed antioxidants are more soluble in organic solvents, and because it is a stable free radical, it is commercially available and avoids its generation in different ways (as with the ABTS method) and facilitating its use (LIMA, 2008). There was a positive correlation between the antioxidant activity by the capture of the ABTS radical and total anthocyanin content $(\mathrm{p} \leq 0.05$, $\mathrm{R} 2=0.85$ for the control treatment and $\mathrm{R} 2=0.99$ for L-ascorbic acid treatment) in red strawberry guava pulps, and no significant correlation was observed with the other compounds analyzed. Other studies have also reported a positive correlation between antioxidant capacity and anthocyanin content in red fruits (MUNHÕZ-ESPADA et al., 2004; KALLITHRAKA et al., 2005; ABE et al., 2007). In the control treatment, there was a positive correlation among the antioxidant activity by DPPH capture method and total phenol and total carotenoid content in yellow strawberry guava pulp $(\mathrm{p} \leq 0.05, \mathrm{R} 2=0.99$ and $\mathrm{R} 2=0.97)$. Dantas et al. (2013), evaluated the antioxidant activity of fruits from different genotypes of strawberry guava trees during maturation and verified that the antioxidant activity increased with the advancement of maturation. The analysis of main components showed that, during maturation, the variability among genotypes was related to the contents of ascorbic acid and carotenoids. Probably the method of extraction and the difference of strawberry guava genotypes may have promoted the discrepancy of the results. There was a positive correlation between antioxidant activity by DPPH capture method and total anthocyanin content $(R 2=1.00, p \leq 0.05)$ in the treatment with L-ascorbic acid. Among the phytochemicals evaluated in the strawberry guava pulps, the ones that were more stable to the storage were anthocyanins, being little affected by the storage at $-20^{\circ} \mathrm{C}$. According to BARRUFALDI and OLIVEIRA (1998), the freezing of food is able to delay almost all its metabolic processes and the lower the storage temperature, the slower the possible changes.

Table 1- Bioactive compound content and antioxidant activity of red strawberry guava pulp (Psidium cattleianum Sabine) during 120 days of frozen storage.

\begin{tabular}{|c|c|c|c|}
\hline Analysis & $\begin{array}{l}\text { Storage time } \\
\quad \text { (days) }\end{array}$ & $\begin{array}{l}\text { Red strawberry } \\
\text { guava pulp } \\
\text { (control) P1c }\end{array}$ & $\begin{array}{l}\text { Red strawberry } \\
\text { guava pulp } \\
\text { (ascorbic acid) P1 }\end{array}$ \\
\hline $\begin{array}{c}\text { Total phenols } \\
\left(\mathrm{mg} \text { gallic acid } 100 \mathrm{~g}^{-1} \mathrm{FW}\right)\end{array}$ & $\begin{array}{c}1 \\
60 \\
120\end{array}$ & $\begin{array}{l}133.03 \pm 0.27^{\mathrm{Bb}} \\
145.99 \pm 0.43^{\mathrm{Ab}} \\
112.08 \pm 2.60^{\mathrm{Cb}}\end{array}$ & $\begin{array}{l}161.40 \pm 2.55^{\mathrm{Aa}} \\
154.69 \pm 0.82^{\mathrm{Ba}} \\
163.32 \pm 1.89^{\text {Аa }}\end{array}$ \\
\hline $\begin{array}{c}\text { Total anthocyanins } \\
\left.\text { (mg cyanidin } 3 \text {-glycoside } 100 \mathrm{~g}^{-1} \mathrm{FW}\right)\end{array}$ & $\begin{array}{c}1 \\
60 \\
120\end{array}$ & $\begin{array}{c}1.41 \pm 0.24^{\mathrm{Aa}} \\
0.97 \pm 0.11^{\mathrm{Bb}} \\
1.33 \pm 0.09^{\mathrm{ABa}}\end{array}$ & $\begin{array}{l}1.43 \pm 0.12^{\mathrm{Aa}} \\
1.69 \pm 0.40^{\mathrm{Aa}} \\
1.12 \pm 0.35^{\text {Aa }}\end{array}$ \\
\hline $\begin{array}{c}\text { Total carotenoids } \\
\left(\mathrm{mg} \beta \text {-carotene } 100 \mathrm{~g}^{-1} \mathrm{FW}\right)\end{array}$ & $\begin{array}{c}1 \\
60 \\
120\end{array}$ & $\begin{array}{l}0.32 \pm 0.05^{\mathrm{Bb}} \\
6.04 \pm 0.92^{\mathrm{Aa}} \\
1.46 \pm 0.71^{\mathrm{Ba}}\end{array}$ & $\begin{array}{l}0.43 \pm 0.02^{\mathrm{Ca}} \\
6.04 \pm 0.05^{\text {Aa }} \\
0.93 \pm 0.20^{\mathrm{Ba}}\end{array}$ \\
\hline $\mathrm{DPPH}^{\circ}(\%$ inhibition $\mathrm{FW})$ & $\begin{array}{c}1 \\
60 \\
120\end{array}$ & $\begin{array}{l}66.35 \pm 2.18^{\mathrm{Bb}} \\
80.83 \pm 0.31^{\mathrm{Aa}} \\
51.60 \pm 2.60^{\mathrm{Cb}}\end{array}$ & $\begin{array}{l}94.14 \pm 0.12^{\mathrm{Aa}} \\
67.21 \pm 0.50^{\mathrm{Cb}} \\
87.67 \pm 1.10^{\mathrm{Ba}}\end{array}$ \\
\hline $\operatorname{ABTS}^{\circ}(\%$ inhibition $\mathrm{FW})$ & $\begin{array}{c}1 \\
60 \\
120\end{array}$ & $\begin{array}{l}59.73 \pm 0.38^{\mathrm{Ba}} \\
77.29 \pm 0.98^{\mathrm{Aa}} \\
57.06 \pm 3.01^{\mathrm{Ba}}\end{array}$ & $\begin{array}{l}89.22 \pm 0.82^{\mathrm{Ab}} \\
36.34 \pm 2.26^{\mathrm{Ba}} \\
19.54 \pm 0.00^{\mathrm{Ca}}\end{array}$ \\
\hline
\end{tabular}

*Values represent the mean $\pm \mathrm{SD}(\mathrm{n}=3)$. Means followed by the same capital letters in the column (among times) do not differ by Tukey test $(\mathrm{p} \leq 0.05)$. Means followed by the same lowercase letters in the line (among treatments) do not differ by $\mathrm{T}$ test $(\mathrm{p} \leq 0.05)$. 
Table 2. Bioactive compound content and antioxidant activity of yellow strawberry guava pulp (Psidium cattleianum Sabine) during 120 days of frozen storage.

\begin{tabular}{|c|c|c|c|}
\hline Analysis & $\begin{array}{l}\text { Storage time } \\
\quad \text { (days) }\end{array}$ & $\begin{array}{l}\text { Yellow strawberry } \\
\text { guava pulp } \\
\text { (control) P2c }\end{array}$ & $\begin{array}{l}\text { Yellow strawberry } \\
\text { guava pulp } \\
\text { (ascorbic acid) P2 }\end{array}$ \\
\hline Total phenols (mg gallic acid $100 \mathrm{~g}^{-1} \mathrm{FW}$ ) & $\begin{array}{c}1 \\
60 \\
120\end{array}$ & $\begin{array}{l}80.86 \pm 0.68^{\mathrm{Bb}} \\
71.39 \pm 1.14^{\mathrm{Cb}} \\
84.98 \pm 2.21^{\mathrm{Ab}}\end{array}$ & $\begin{array}{l}123.84 \pm 0.20^{\mathrm{Aa}} \\
104.23 \pm 0.36^{\mathrm{Ca}} \\
113.25 \pm 1.42^{\mathrm{Ba}}\end{array}$ \\
\hline $\begin{array}{c}\text { Total anthocyanins } \\
\text { (mg cyanidin } 3 \text {-glycoside } 100 \mathrm{~g}^{-1} \mathrm{FW} \text { ) }\end{array}$ & $\begin{array}{c}1 \\
60 \\
120\end{array}$ & $\begin{array}{c}1.74 \pm 1.09^{\mathrm{ABa}} \\
1.00 \pm 0.21^{\mathrm{Ba}} \\
3.60 \pm 0 . .^{70 \mathrm{~A}} \mathrm{a}\end{array}$ & $\begin{array}{l}3.24 \pm 0.20^{\mathrm{Aa}} \\
0.54 \pm 0.01^{\mathrm{Cb}} \\
1.23 \pm 0.38^{\mathrm{Bb}}\end{array}$ \\
\hline $\begin{array}{c}\text { Total carotenoids } \\
\left(\mathrm{mg} \beta \text {-carotene } 100 \mathrm{~g}^{-1} \mathrm{FW}\right)\end{array}$ & $\begin{array}{c}1 \\
60 \\
120\end{array}$ & $\begin{array}{l}0.40 \pm 0.05^{\mathrm{Ba}} \\
5.25 \pm 0.60^{\mathrm{Aa}} \\
1.14 \pm 0.18^{\mathrm{Aa}}\end{array}$ & $\begin{array}{l}0.49 \pm 0.04^{\mathrm{Ca}} \\
4.65 \pm 0.24^{\mathrm{Aa}} \\
1.24 \pm 0.09^{\mathrm{Ba}}\end{array}$ \\
\hline $\mathrm{DPPH}^{\circ}(\%$ inhibition FW) & $\begin{array}{c}1 \\
60 \\
120\end{array}$ & $\begin{array}{l}29.52 \pm 1.02^{\mathrm{Bb}} \\
40.65 \pm 0.38^{\mathrm{Aa}} \\
27.81 \pm 1.17^{\mathrm{Bb}}\end{array}$ & $\begin{array}{l}43.82 \pm 0.32^{\mathrm{Aa}} \\
30.87 \pm 0.82^{\mathrm{Cb}} \\
36.19 \pm 0.18^{\mathrm{Ba}}\end{array}$ \\
\hline $\mathrm{ABTS}^{\circ}(\%$ inhibition $\mathrm{FW})$ & $\begin{array}{c}1 \\
60 \\
120\end{array}$ & $\begin{array}{l}25.00 \pm 0.38^{\mathrm{Ba}} \\
33.77 \pm 0.50^{\mathrm{Aa}} \\
21.73 \pm 0 .{ }^{98} \mathrm{Ca}\end{array}$ & $\begin{array}{l}40.03 \pm 0.82^{\mathrm{Ab}} \\
28.63 \pm 0.30^{\mathrm{Bb}} \\
22.44 \pm 0 .{ }^{00} \mathrm{Ca}\end{array}$ \\
\hline
\end{tabular}

*Values represent the mean $\pm \mathrm{SD}(\mathrm{n}=3)$. Means followed by the same capital letters in the column (amongtimes) do not differ by Tukey test $(\mathrm{p} \leq 0.05)$. Means followed by the same lowercase letters in the line (among treatments) do not differ by $\mathrm{T}$ test ( $\mathrm{p} \leq 0.05)$.

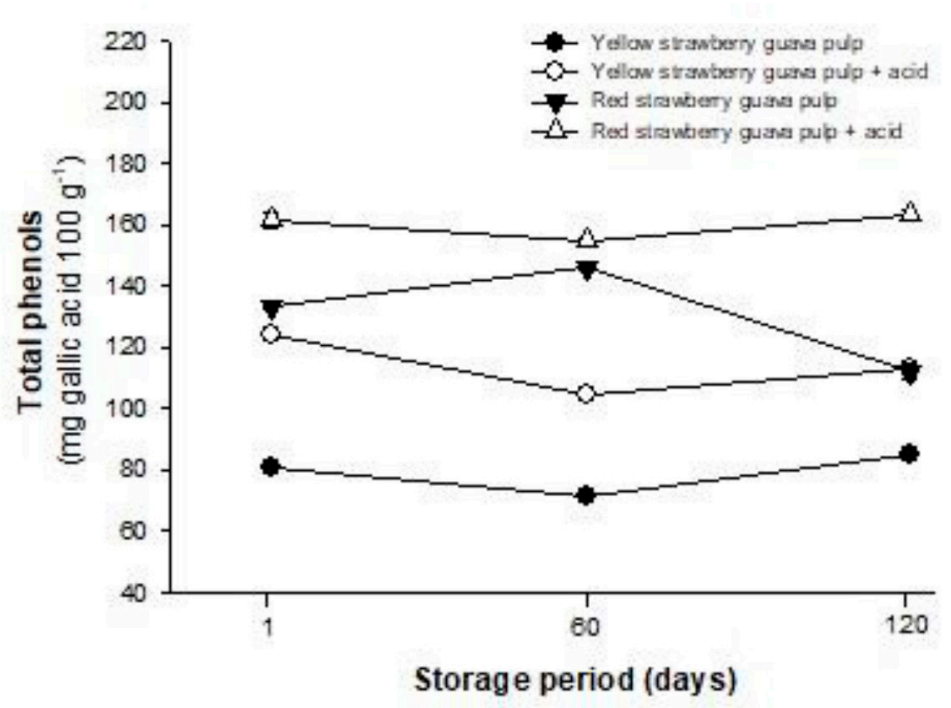

Figure 1. Total phenols of red and yellow strawberry guava pulp (Psidium cattleianum Sabine) during 120 days of frozen storage. Values represent the mean $\pm \mathrm{SD}(\mathrm{n}=3)$. 


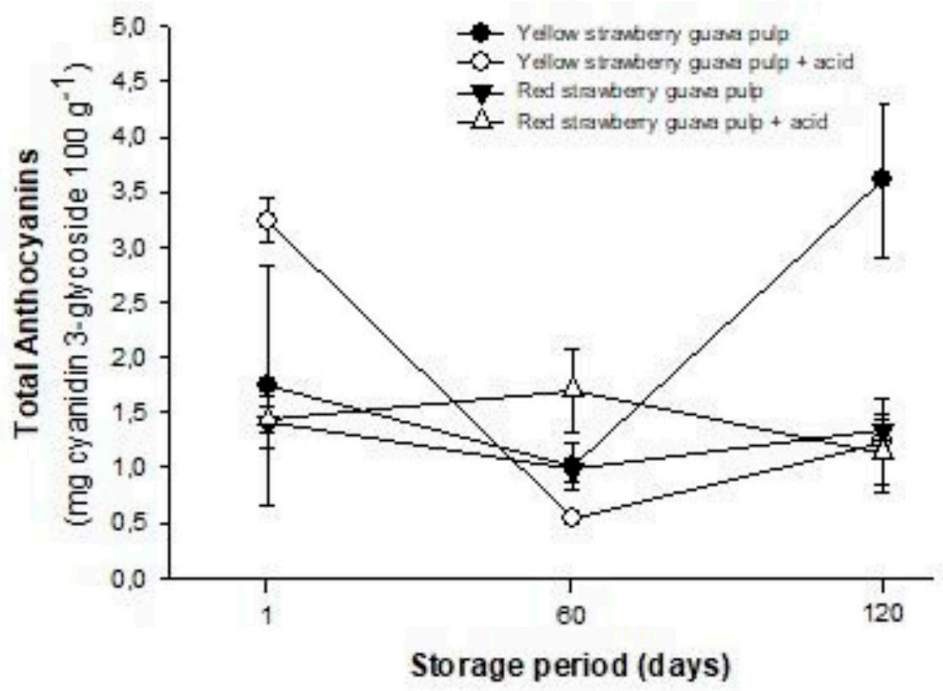

Figure 2. Total anthocyanins of red and yellow strawberry guava pulp (Psidium cattleianum Sabine) during 120 days of frozen storage. Values represent the mean $\pm \mathrm{SD}(\mathrm{n}=3)$.

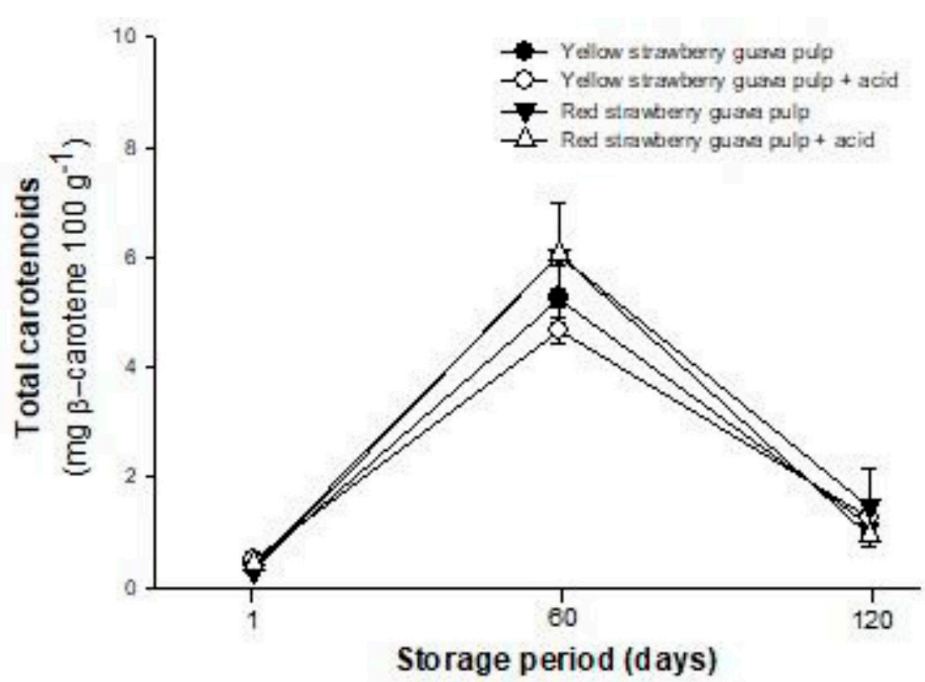

Figure 3. Total carotenoids of red and yellow strawberry guava pulp (Psidium cattleianum Sabine) during 120 days of frozen storage. Values represent the mean $\pm \mathrm{SD}(\mathrm{n}=3)$.
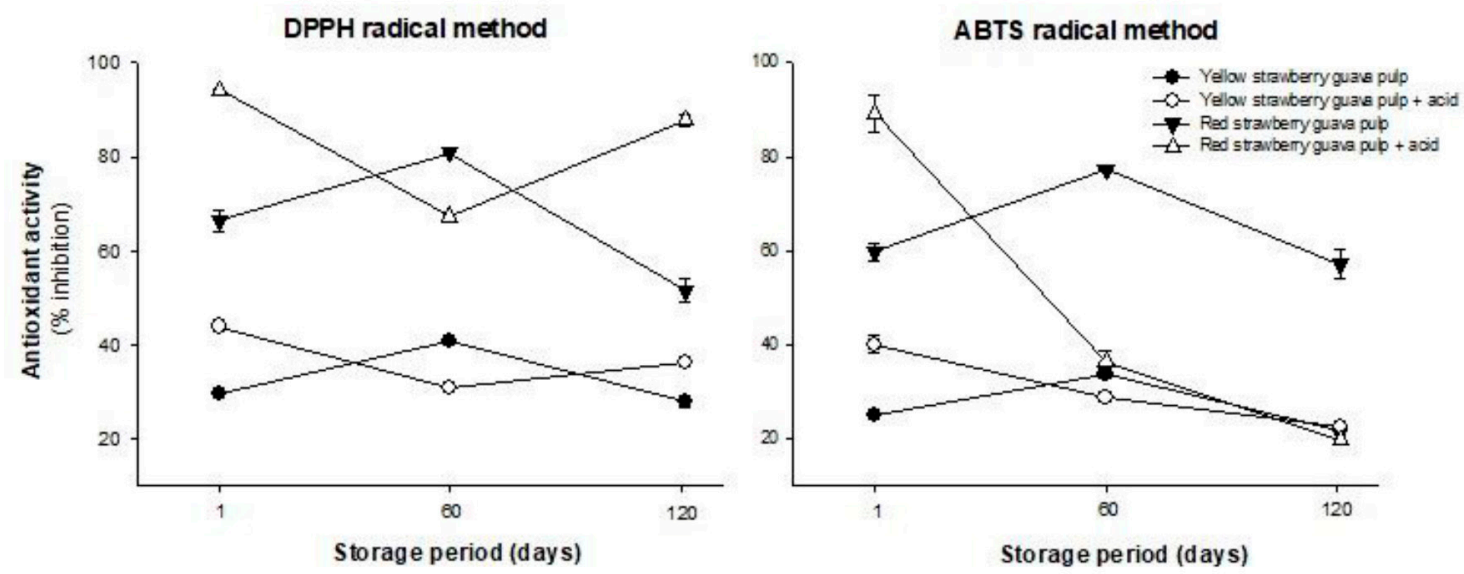

Figure 4. Antioxidant activity of red and yellow strawberry guava pulp (Psidium cattleianum Sabine) during 120 days of frozen storage. Values represent the mean $\pm \mathrm{SD}(\mathrm{n}=3)$. 


\section{Conclusion}

L-ascorbic acid positively influences the retention of bioactive compounds (total phenols, total anthocyanins, and total carotenoids) in red and yellow fruit pulp during 120 days of frozen storage, when compared to the control treatment, making it viable as an antioxidant additive in frozen pulps at $-20^{\circ} \mathrm{C}$.

\section{Acknowledgements}

This study had financial support from the Foundation for Research Support of the State of Rio Grande do Sul (FAPERGS). The authors are also grateful to Embrapa Temperate Climate - Pelotas / RS for providing the red and yellow strawberry guava fruits.

\section{References}

ABE, L. T., DA MOTA, R. V., LAJOLO, F. M., GENOVESE, M. I. Compostos fenólicos e capacidade antioxidante de cultivares de uvas Vitis labrusca L. e Vitis vinifera L. Ciência e Tecnologia de Alimentos, Campinas, v.27, n.2, p.394-400, 2007.

AOAC - Association of Official Analytical Chemists. Official methods of analysis of AOAC. $18^{\text {th }}$ ed. Gaithersburg, 2005.

AQUINO, A.C.M.de.S.; MÓES, R.S.; CASTRO, A.A. Estabilidade de ácido ascórbico, carotenoides e antocianinas de frutos de acerola congelados por métodos criogênico. Brazilian Journal of Food Technology, Campinas, v.14, n.2, p. 154-163, 2011.

ARAÚJO, P.F. de; RODRIGUES, R. da SILVA.; MACHADO, A.R.; SANTOS, V. da SILVA.; SILVA, J.A. Influência do congelamento sobre as características físicoquímicas e o potencial antioxidante de néctar de amorapreta. Boletim do Centro de Pesquisa de Processamento de Alimentos, Curitiba, v.27, n.2, p.199-206, 2009.

BALDI, A.; ROMANI, A.; MULINACCI, N.; VINCIERI, F.F.; CASETTA, B. HPLC/MS application to anthocyanins of Vitis Vinifera L. Journal of Agricultural Food Chemistry, Washington, v.43, p.2104-2109, 1995.

BARRETO, C.F.; MORENO, M.B.; SILVA, P.S.da.; FARIAS, R.DE.M.; FACHINELLO, J.C.; MARTINS, C.R. Conservação de maçãs 'Fuji Suprema' minimamente processados. Revista Iberoamericana de Tecnología Postcosecha, México, v.17, n.1, p.99-105, 2016.
BARRUFALDI, R.; OLIVEIRA, M. N. de. Fundamentos de tecnologia de alimentos. São Paulo: Atheneu Editora, 1998. v.3.

BIEGELMEYER, R.; ANDRADE, J.M.M.; ABOY, A.L.; APEL, M.A.; DRESCH, R.R.; MARIN, R.; RASEIRA, M.do C.B.; HENRIQUES, A.T. Comparative Analysis of the Chemical Composition and Antioxidant Activity of Red (Psidium cattleianum) and Yellow (Psidium cattleianum var. lucidum) Strawberry Guava Fruit. Journal of Food Science, Chicago, v.76, n.7, p.991-996, 2011.

BOBBIO, G. O.; BOBBIO, P. A. Química do processamento de alimentos. 2. ed. São Paulo: Editora Varela, 1992.

BOULTON, R. The copigmentation of anthocyanins and its role in the color of red wine: a critical review. American Journal of Enology and Viticulture, Davis, v.52, n.2, p.67-80, 2001.

BOYLES, M.J.; WROLSTAD, R.E. Anthocyanin composition of red raspberry juice: Influences of cultivar, processing, and environmental factors. Journal of Food Science, Chicago, v.58, p.1135-1141. 1993.

BRAND-WILLIANS, W.; CUVELIER, M. E.; BERSET, C. Use of a free radical method to evaluate antioxidant activity. Food Science and Technology, Tokyo, v.28, p.25-30, 1995.

BROUILLARD, R., The in vivo expression of anthocyanin colour in plants, Phytochemistry, v.22, p.1311-1323, 1983.

BRASIL. Instrução Normativa $n^{\circ} 08$, de 06 de março de 2013. Aprovação de uso de aditivos alimentares para produtos de frutas e de vegetais e geleia de mocotó. Diário Oficial da União, Brasília, DF, 08 mar. 2013, n.46, Seção 1, p.68.

CASTELUCCI, A. C. L. Avaliação da qualidade dos compostos bioativos de polpas de frutas nativas submetidas ao processo de irradiação. 2015. $135 \mathrm{f}$. Tese (Doutorado) - Centro de Energia Nuclear na Agricultura da Universidade de São Paulo, Piracicaba, 2015.

CRIZEL, R.; LEMKE, E.; ZANDONÁ, G.; ARANHA, B.; CHAVES, F. Potencial funcional de polpas de araçá amarelo (Psidium cattleianum) e de butiá (Butia odorata). Revista da jornada de pós-graduação e pesquisa - Congrega, 2017. Disponível em: <http://trabalhos. congrega.urcamp.edu.br/index.php/14jpgp/article/ view/2900/1298> 
DANTAS, A.L.; SILVA, S. de M.; LIMA, M.A.C. de; DANTAS, R.L.; MENDONÇA, R.M.N. Bioactive compounds and antioxidant activity during maturation of strawberry guava fruit. Revista Ciência Agronômica, Fortaleza, v.44 n.4, 2013.

DENARDIN, C.C.; HIRSCH, G.E.; DA ROCHA, R.F.; VIZZOTTO, M.; HENRIQUES, A.T.; MOREIRA, J.C.F.; GUMA, F.T.C.R.; EMANUELLI, T. Antioxidant capacity and bioactive compounds of four Brazilian native fruits. Journal of Food and Drug Analysis, Amsterdam, v.23, n.3, p.387-398, 2015.

FALCÃO, L. D.; BARROS, D. M.; GAUCHE, C.; LUIZ, M. T. B. Copigmentação intra e intermolecular de antocianinas: uma revisão. Boletim CEPPA, Curitiba, v.21, n.2, p.351-366, 2003.

FRANZON, R. C. Espécies de araçás nativos merecem maior atenção da pesquisa. Planaltina: Embrapa Cerrados, 2009. Disponível em: <http://www.cpac. embrapa.br/noticias/artigosmidia/publicados/133/>. Acesso em: 20 nov. 2015.

JACQUES, A.C.; PERTUZATTI, P.B.; BARCIA, M.T.; ZAMBIAZI, R.C. Compostos bioativos em pequenas frutas cultivadas na região sul do estado do Rio Grande do Sul. Brazilian Journal of Food technology, Campinas, v.12, n.12, p.123-127, 2009.

JURD, L. Some advances in the chemistry of anthocyanin-type plant pigments. In: The chemistry of plant pigments. New York: Academic Press, 1972. p.123-187,

KALLITHRAKA, S.; MOHDALY, A. A.; MAKRIS, D.P.; KEFALAS, P. Determination of major anthocyanin pigments in Hellenic native grape varieties (Vitis vinifera sp.): association with antiradical activity. Journal of Food Composition and Analysis, New York, v.18, p.375-386, 2005 .

LEES, D.H.; FRANCIS, F.J. Standardization of pigment analyses in cranberries. HortScience, Alexandria, v.7, p.83-84, 1972.

LIMA, A. Caracterização química, avaliação da atividade antioxidante in vitro $\mathrm{e}$ in vivo, e identificação dos compostos fenólicos presentes no pequi (Caryocar brasiliense, camb.). 2008. Tese (Doutorado em Bromatologia) - Universidade de São Paulo, São Paulo, 2008.
LOPES, A.S.; MATTIETTO, R. de A.; MENEZES, H.C. de. Estabilidade da polpa de pitanga sob congelamento. Ciência e Tecnologia de Alimentos, Campinas, v.25, n.3, p.553-559, 2005.

LORENZI, H.; BACHER, L.; LACERDA, M.; SARTORI, $\mathrm{S}$. Frutas brasileiras e exóticas cultivadas (de consumo in natura). São Paulo: Instituto Plantarum de Estudos da Flora, 2006. 640p.

MAEDA, R. N.; PANTOJA, L.; YUYAMA, L. K. O.; CHAAR, J. M. Estabilidade de ácido ascórbico e antocianinas em néctar de camu-camu (Myrciaria dubia (H. B. K.) McVaugh). Ciência e Tecnologia de Alimentos, Campinas, v.27, n.2, 313-316, 2007.

MARSHALL, M. R.; KIM, J.; WEI, C. Enzymatic browning in fruits, vegetables and sea foods. Washington: FAO, 2000. Disponível em: $\leq \mathrm{http}: / /$ www.fao.org/ag/ags/ agsi/enzymefinal/enzymatic\%20browning.htm $>$. Acesso em: 5 jun. 2016.

MAZZA, G.; MINIATI, E. Anthocyanins in fruits, vegetables, and grains. London: CRC Press, 1993. $362 p$.

MENEZES, J.B. Pós-colheita do pedúnculo do caju. Informe Agropecuário, Belo Horizonte, v.17, n. 180, p.13-17, 1994.

MUNHOZ, P.C.; PEREIRA, E.S.; SCHIAVON, M.V.; SANTOS, D.C.; VIZZOTTO, M. Caracterização química de frutas nativas vermelhas: araçá vermelho, cereja-do rio-grande, pitanga e jabuticaba. In: ENCONTRO SOBRE PEQUENAS FRUTAS E FRUTAS NATIVAS DO MERCOSUL, 6., 2014, Pelotas. Resumos e palestras... Pelotas: Embrapa Clima Temperado, 2014. v.1, p.134134.

MUÑOZ-ESPADA, A.C.; WOOD, K.V.; BORDELON, B.; WATKINS, B.A. Anthocyanin quantiication and radical scavening capacity of Concord, Norton, and Marechal Foch Grapes and wines. Journal of Agriculture and Food Chemistry, Washington, v.52, n.22, p.67796786, 2004.

NORA, C.D. Caracterização, atividade antioxidante "in vivo" e efeito do processamento na estabilidade de compostos bioativos de araçá vermelho e guabiju. 2012. 91 f. Dissertação (Mestrado) - Programa de PósGraduação em Ciência e Tecnologia de Alimentos, Universidade Federal do Rio Grande do Sul, Porto Alegre, 2012. 
PALIYATH, G.; MURR, D.P.AVTAR, K.; HANDA, S.L. Postharvest biology and technology of fruits, vegetables and flower. Hoboken: Wiley-Blackwell, 2008. 498p.

RE, R.; PELleGrini, N.; PROTEGGEnte, A.; PANNALA, A.; M, YANG.; RICE-EVANS, C. Antioxidant activity applying an improved ABTS radical cation decolorization assay. Free Radical Biology and Medicine, New York, v.26, n.9/10, p.1231-1237, 1999.

REISSIG, G.N. Araçá-vermelho (Psidium cattleianum Sabine). Revista Brasileira de Fruticultura, v.38, n.3, e 062, 2016.

RIBEIRO, E. P.; SERAVALLI, E. A. G. Química de alimentos. 2.ed. São Paulo: Editora Edgard Blucher, 2007. $184 p$.

RIBEIRO, A.B.; CHISTÉ, R.C.; FREITAS, M.; da SILVA, A.F.; VISENTAINER, J.V.; FERNADES, E. Psidium cattleianum fruit extracts are efficient in vitro scavengers of physiologically relevant reactive oxygen and nitrogen species. Food Chemistry, New York, v.165, p.140-148, 2014.

RODRIGUEZ-AMAYA, D.B.; KIMURA, M.; AMAYAFARFAN, J. Fontes brasileiras de carotenoides: tabela brasileira de composição de carotenoides em alimentos. Brasília: MMA/SBF, 2008. 100p. Disponível em: $<\underline{\text { http:// }}$ www.mma.gov.br/estruturas/sbf agrobio/_publicacao/89 publicacao09032009113306.pdf > . Acesso em: 11 fev. 2016.

RUFINO, M.S.M.; ALVES, R.E.; BRITO, E.S.; MORAIS, S.M.; SAMPAIO, C.G.; PÉREZ-JIMÉNEZ, J.; SAURACALIXTO, F.D. Metodologia científica: Determinação da atividade antioxidante total em frutas pela captura do radical livre ABTS ${ }^{+}$. Fortaleza: Embrapa, 2007. 4p. (Comunicado Técnico)

SAPERS, G. M.; MILLER, R. L. Browning inhibition in fresh-cut pears. Journal Food Science, Chicago, v.63, n.2, p.342-346, 1998.

SCALBERT, A.; WILLIAMSON, G. Dietary intake and bioavailability of polyphenols. Journal of Nutrition, Bethesda, v.130, p.2073-2085. 2000.
SELLAPPAN, S.; AKOH, C.C.; KREWER, G. Phenolic compounds and antioxidant capacity of Georgia- grown blueberries and blackberries. Journal of Agricultural and Food Chemistry, Washington, v.50, p.2432-2438, 2002.

SHIASSI, M.C.E.V.; SOUZA, V.R.de.; LAGO, A.M.T.; CAMPOS, L.G.; QUEIROZ, F. Fruits from the brazilian cerrado region: Physico-chemical characterization, bioactive compounds, antioxidant activities, and sensory evaluation. Food Chemistry, New York, v.245, p.305$311,2018$.

SINGLETON, V.L.; ROSSI, J.A. JR. Colorimetry of total phenolics with phosphomolybdic-phosphotungstic acid reagents. American Journal of Enology and Viticulture, Davis, v.16, p.144-158, 1965.

SOUZA, V.R.; PEREIRA, P.A.P.; QUEIROZ, F.; BORGES, S.V.; CARNEIRO, J.D.S. Determination of bioactive compounds, antioxidant activity and chemical composition of Cerrado Brazilian fruits. Food Chemistry, New York, v.134, p.381-386, 2012.

STATSOFT. Programa computacional Statistica 7.0. 2004.

TIMBERLAKE, C.F. Anthocyanins occurrence, extraction and chemistry. Food

Chemistry, New York, n.5, p.69-80, 1980.

TOMÁS-BARBERÁN, F.A.; ESPÍN, J.C. Phenolic compounds and related enzymes as determinants of quality in fruits and vegetables. Journal of the Science of Food and Agriculture, Chicago, n.81, p.853- 879, 2001.

VILAS BOAS, E.V.B. Qualidade de alimentos vegetais. Lavras: UFLA/FAEPE, 2002. p.59.

VIZZOTTO, M.; BIALVES, T.S.; ARAUJO, V.F.; NACHTIGAL, J.C. Polpas de frutas: fonte de compostos antioxidantes. Anais do $4^{\circ}$ Simpósio de Segurança Alimentar. In: SIMPÓSIO DE SEGURANÇA ALIMENTAR: RETORNO ÀS ORIGENS, 4., 2012, Gramado. Anais... 3p.

ZHANG, Z.; PANG, X.; XUEWU, D.; JI, Z.; JIANG, Y. Role of peroxidase in anthocyanin degradation in litchi fruit pericarp. Food Chemistry, New York, v.90, p.47-52, 2005. 